\title{
Synthesis of Membrane and Periplasmic Proteins during Starvation of a Marine Vibrio sp.
}

\author{
By THOMAS NYSTRÖM, NAN ALBERTSON AND \\ STAFFAN KJELLEBERG* \\ Department of Marine Microbiology, University of Göteborg, Carl Skottsbergs Gata 22, \\ S-413 19 Göteborg, Sweden
}

(Received 18 November 1987; revised 21 January 1988)

\begin{abstract}
Changes in membrane and periplasmic protein profiles induced by starvation conditions in the marine Vibrio sp. S14 were examined by one-dimensional gel electrophoresis. Analysis by densitometry resolved at least six periplasmic proteins, nine outer membrane proteins, and four cytoplasmic membrane proteins induced at various times during $120 \mathrm{~h}$ of nutrient and energy starvation. Eight of these were also synthesized by heat- and/or ethanol-shocked cells. Pulselabelling indicated that the starvation-induced proteins were not products of degradation, and that their synthesis was differently modulated during starvation. The most pronounced changes occurred during the initial hours of nutrient and energy deprivation. The correlation between the initial changes in protein composition and utilization of the intracellular energy reserve poly$\beta$-hydroxybutyrate is discussed. The rate of proteolysis during the initial hours of starvation was approximately 16 times greater than that during exponential growth.
\end{abstract}

\section{INTRODUCTION}

Growth of heterotrophic bacteria in marine environments is inhibited by periods of insufficient energy and nutrients (e.g. Wheeler \& Kirchman, 1986). The long-term survival of marine bacteria in energy- and nutrient-limited microcosms is well documented (Morita, 1985). The Vibrio sp. S14 used in this study remains $100 \%$ viable after 1 week in unsupplemented artificial seawater (Nyström \& Kjelleberg, 1987), and is culturable after 6 months in the starvation regime (unpublished data). By comparison, other well-defined laboratory strains used in starvation studies, such as Escherichia coli K12 and Salmonella typhimurium, sustained only 40 and $30 \%$ viability respectively after 1 week in similar conditions (Reeve et al., 1984a).

Several factors may contribute to the prolonged survival of starved cells. The importance of protein synthesis during starvation has been shown by the decreased survival of $E$. coli when amino acid analogues are supplied or when protein synthesis is inhibited (Reeve et al., 1984b). Increased survival after other shifts in exogenous conditions may also involve specific protein synthesis. Some of the proteins synthesized in $E$. coli and $S$. typhimurium during carbon starvation are also observed in the heat-shock, SOS, and other stress responses (Gottesman, 1984; Spector et al., 1986; Groat \& Matin, 1986).

Starvation conditions result in changes in the protein makeup of marine strains, as demonstrated by two-dimensional gel electrophoresis (Jouper-Jaan et al., 1986; Amy \& Morita, 1983) and by the production of starvation-specific antibodies (Albertson et al., 1987). A comparison of the changes in protein composition indicated that three marine isolates exhibited different patterns of synthesis and degradation in response to the starvation conditions (JouperJaan et al., 1986). Changes in protein makeup during starvation have also been demonstrated for the marine Vibrio Ant 300 (Amy \& Morita, 1983). However, in these experiments changes due to

\footnotetext{
Abbreviations: CMP, cytoplasmic membrane protein(s); OMP, outer membrane protein(s); PP, periplasmic protein(s); PHB, poly- $\beta$-hydroxybutyrate.
} 
specific starvation-induced synthesis cannot be distinguished from proteolytic modification. An overlap in the set of genes expressed during starvation and recognized stress regulons (e.g. the heat-shock response, the SOS response) has not been investigated in marine organisms. Three questions with respect to membrane and periplasmic proteins are addressed in this study. (i) Are the starvation proteins previously detected in Vibrio S14 (Albertson et al., 1987; Jouper-Jaan et al., 1986) results of de novo synthesis during starvation or of proteolytic modification? (ii) Is the synthesis of starvation proteins a result of sequential induction during the starvation period studied $(120 \mathrm{~h})$ ? (iii) Is there an overlap between the proteins induced by starvation and by heatand ethanol-shock in the marine Vibrio sp. S14? Possible functions of the starvation-induced proteins are discussed.

\section{METHODS}

Organism, cultivation and starvation conditions. The marine Vibrio sp. S14 (CCUG 15956) used in this study is described by Mårdén et al. (1987). S14 was grown on VNSS, containing $1.0 \mathrm{~g}$ peptone, $0.5 \mathrm{~g}$ yeast extract, $0.5 \mathrm{~g}$ glucose, $0.5 \mathrm{~g}$ starch, $0.01 \mathrm{~g} \mathrm{FeSO}_{4} .7 \mathrm{H}_{2} \mathrm{O}, 0.01 \mathrm{~g} \mathrm{Na}_{2} \mathrm{HPO}_{4}$ per litre NSS. A nine-salt solution (NSS) was used for washing the bacteria and in the starvation regime (Mården et al., 1985). A minimal medium (MNSS) containing

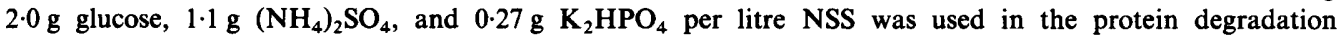
experiments. Cells were grown and starvation regimes prepared as described by Albertson et al. (1987). Cells starved for $0,3,5,10,24$ and $120 \mathrm{~h}$ were analysed in this study.

Labelling of cells and analysis by SDS-PAGE. Samples $(20 \mathrm{ml})$ of cells were pulse-labelled for $10 \mathrm{~min}$ with $3.4 \mathrm{nmol} \mathrm{L}-\left[4,5-{ }^{3} \mathrm{H}\right]$ leucine (specific activity $4.44 \times 10^{6} \mathrm{MBq} \mathrm{mmol}^{-1}$, New England Nuclear) during growth and at appropriate intervals during starvation. Incorporation was terminated by the addition of $100 \mu \mathrm{g}$ nonradioactive leucine $\mathrm{ml}^{-1}$. The cell suspension was centrifuged, fractionated (Achtman et al., 1983), and proteins from membrane and periplasmic fractions were solubilized, and separated by electrophoresis as previously described (Albertson et al, 1987). The gels were stained with Coomassie blue and analysed by densitometry at $633 \mathrm{~nm}$ (LKB UltroScan XL 2220). To determine the radioactivity incorporated into specific proteins, the gels were sliced $(1 \mathrm{~mm})$ and the radioactivity was measured after digestion overnight $\left(37^{\circ} \mathrm{C}\right)$ with Econofluor containing $7.5 \%$ Protosol (New England Nuclear). Cells labelled and fractionated in two separate experiments resulted in similar incorporation and protein patterns.

Heat- and ethanol-shock. Cells were grown to a density of $2 \times 10^{8}$ cells ml-1 $^{-1}$ in VNSS, then centrifuged and suspended into new media: VNSS at $26^{\circ} \mathrm{C}$ (control), VNSS at $40{ }^{\circ} \mathrm{C}$, and VNSS containing $10 \%(\mathrm{v} / \mathrm{v})$ ethanol. Turbidity was followed spectrophotometrically $(610 \mathrm{~nm})$ and viability was monitored by measurement of the number of respiring cells (Zimmerman et al., 1978). Cells were harvested after $30 \mathrm{~min}$, fractionated, and analysed by gel electrophoresis.

Determination of protein degradation. A $20 \mathrm{ml}$ culture of Vibrio sp. S14 was grown for two generations in VNSS supplemented with 3.4 nmol L-[4,5-3 $\mathrm{H}] \mathrm{leucine}\left(4.44 \times 10^{6} \mathrm{MBq} \mathrm{mmol}^{-1}\right.$; New England Nuclear). The cells were then harvested, washed twice, and suspended in three different media each containing $100 \mu \mathrm{g}$ nonradioactive leucine $\mathrm{ml}^{-1}$. Protein degradation was determined in growing cells (VNSS, generation time $40 \mathrm{~min}$ ), in cells grown on amino-acid-deficient minimal medium (MNSS, generation time $170 \mathrm{~min}$ ), and in cells starved for both nutrients (phosphorus and nitrogen) and carbon (NSS). The rate of protein degradation was expressed as the percentage of the zero-time TCA-precipitable counts released as TCA-soluble material per hour, according to Reeve et al. (1984a).

Protein determination. Protein concentrations were determined by the method of Whitaker \& Granum (1980). Samples were prepared according to Nyström et al. (1986).

\section{RESULTS}

\section{Synthesis of individual proteins during starvation and heat- and ethanol-shock}

Representative polypeptide patterns of outer membrane fractions obtained from growing and starved $(10 \mathrm{~h})$ cells are presented in Fig. 1, and periplasmic protein patterns of growing and starved $(24 \mathrm{~h})$ cells are presented in Fig. 2 . The proteins that increased in synthesis relative to the non-starved control are marked. The synthesis of different proteins was initiated throughout the starvation period $(120 \mathrm{~h})$, resulting in the induction of nine outer membrane proteins, six periplasmic proteins and four cytoplasmic membrane proteins (Fig. 3). Heat-shock induced sixteen proteins, seven of which over-lapped with the starvation-induced proteins. Ethanol treatment resulted in the synthesis of fifteen new polypeptides. Eight of these were also 


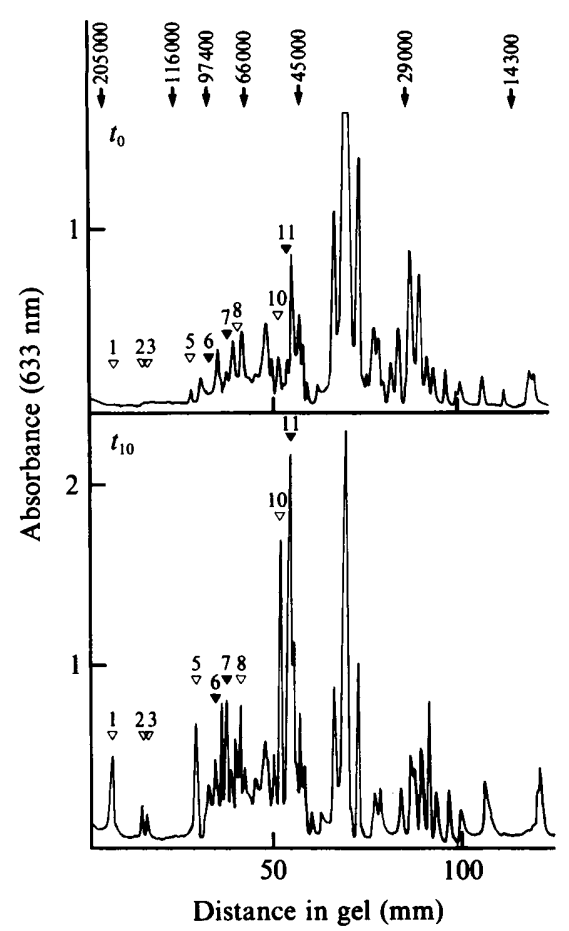

Fig. 1

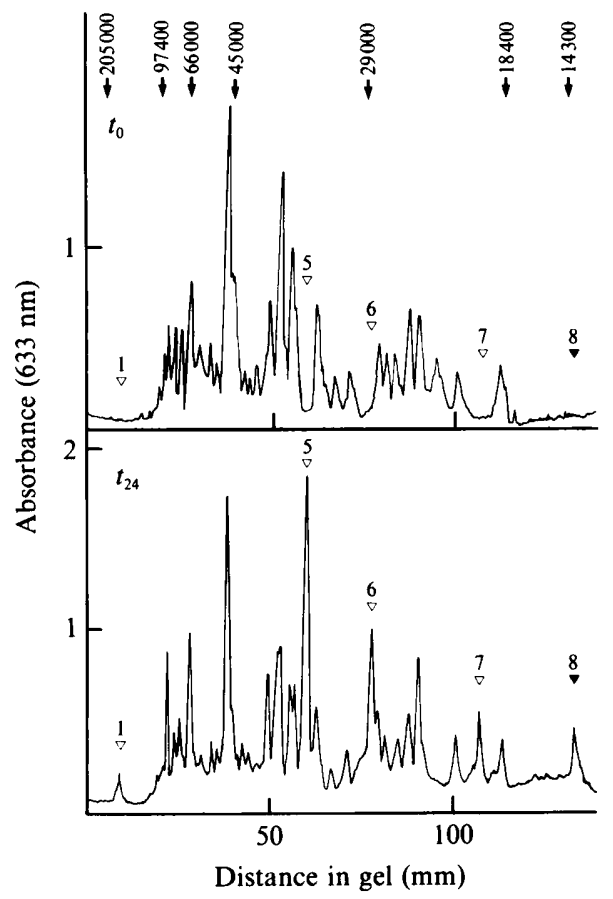

Fig. 2

Fig. 1. PAGE of outer membrane proteins after 0 and $10 \mathrm{~h}$ of starvation. Gels were stained overnight with Coomassie blue and scanned at $633 \mathrm{~nm}$. Starvation-specific proteins $(\nabla)$, and starvation proteins inducible by heat- and ethanol-shock $(\nabla)$ are indicated. $M_{\mathrm{r}}$ values of proteins in the reference standard are indicated. The experiments were done in triplicate with insignificant deviations between replicates.

Fig. 2. PAGE of periplasmic proteins after 0 and $24 \mathrm{~h}$ of starvation. See Fig. 1 for methodology and symbols.

\begin{tabular}{|c|c|c|c|c|c|c|c|c|c|c|c|c|c|c|c|c|c|c|c|c|c|c|c|}
\hline & \multicolumn{13}{|c|}{ OMP } & \multicolumn{7}{|c|}{ PP } & \multicolumn{3}{|c|}{ CMP } \\
\hline & 1 & 2 & 3 & 5 & 6 & 7 & 9 & 10 & 11 & 12 & 13 & 14 & 15 & 1 & 2 & \begin{tabular}{l|l|l}
3 & 4
\end{tabular} & 5 & \begin{tabular}{l|l}
6 & 7 \\
\end{tabular} & 78 & 9 & \begin{tabular}{l|l}
1 & 2
\end{tabular} & & \begin{tabular}{l|l}
4 & 5
\end{tabular} \\
\hline Starvation indu & & & & & & & & & 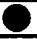 & & & & & & & & & & & & & & \\
\hline Ethanol inducit & & & & & & & & & 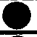 & 0 & & & & & & & & & & & & & \\
\hline Heat inducible & & & & & & & & & & 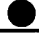 & & & & & & & & & & & & & \\
\hline
\end{tabular}

Fig. 3. Schematic diagram of the overlap among stress responses. The filled boxes represent proteins that are induced by a given stress as determined by one-dimensional gel densitometry analysis. The top line shows the numerical designation of each protein according to its position on the gel; the lower numbers designate the larger proteins. OMP, outer membrane proteins; PP, periplasmic proteins; CMP, cytoplasmic membrane proteins.

identified as starvation-inducible proteins. The locations of the heat- and ethanol-inducible proteins, and the extent of overlap between the two treatments, are depicted in Fig. 3. Proteins induced by heat overlapped significantly with those induced by ethanol treatment, where thirteen were identical. In the cytoplasmic membrane, four starvation-induced proteins were detected, all of which were also induced by heat- and/or ethanol-shock (Fig. 3).

To ensure that the proteins studied were the result of de novo synthesis, cells were pulselabelled during starvation, and the incorporated radioactivity in the proteins eluted from gels was measured. The radioactivity incorporated into two periplasmic proteins, PP1 and PP5, was determined at 0,3 and $24 \mathrm{~h}$ of starvation (Fig. 4). The rate of synthesis of PP5 was highest at $3 \mathrm{~h}$ 


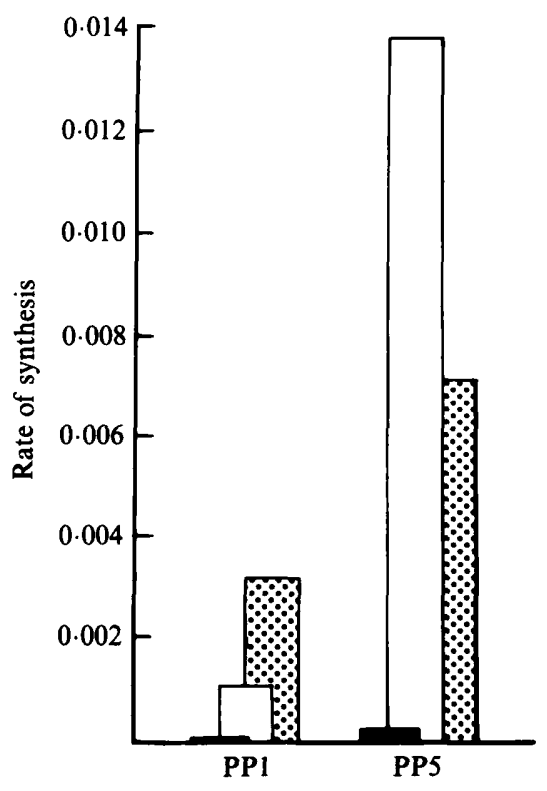

Fig. 4

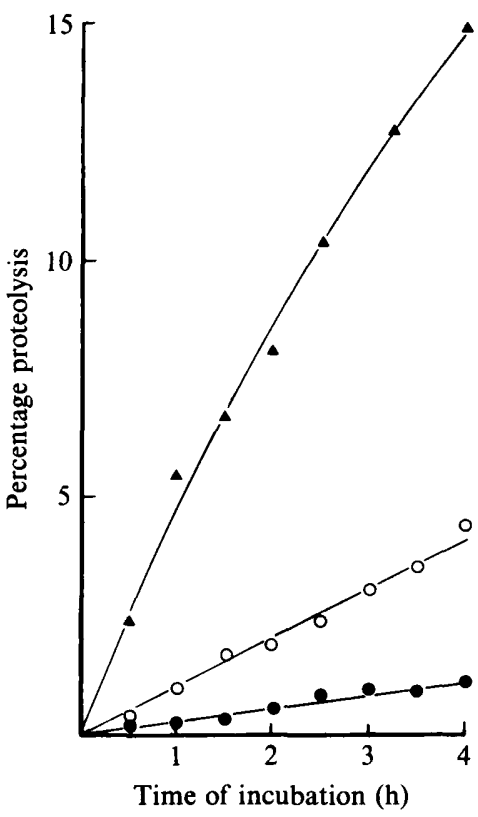

Fig. 5

Fig. 4. Rate of synthesis of the starvation-specific periplasmic proteins PPl and PP5 at $0(\square), 3(\square)$, and $24(-3) \mathrm{h}$ of starvation. The synthesis rate was calculated by dividing the radioactivity from each gel slice by the total radioactivity loaded on the gel. The experiments were done in duplicate with insignificant deviations between replicates.

Fig. 5. Protein degradation in starving cells $(\boldsymbol{\Delta})$ and in cells growing on VNSS $(\boldsymbol{O})$ or MNSS $(O)$ medium. Percentage proteolysis was calculated as

$$
\frac{\text { (TCA-soluble d.p.m. after time } t \text { chase) }- \text { (TCA-soluble d.p.m. at time } 0 \text { chase) }}{\text { TCA-precipitable d.p.m. at time } 0 \text { chase }} \times 100
$$

The experiments were done in duplicate with insignificant deviations between replicates.

of starvation, when it comprised $1.4 \%$ of the total radioactivity incorporated by the cell during the pulse period. This rate had decreased at $24 \mathrm{~h}$ of starvation although it was still at least 30 times that found at the onset of starvation. This pattern of synthesis, with a maximum in rate at 3 or $5 \mathrm{~h}$ of starvation, was the most common found in the proteins examined (i.e. PP5, 7, 8, OMP5, $6,7,11$ and CMP1, 2, 3, 4). However, the rate of synthesis of other proteins (PP1, 6 and OMP10) increased during starvation, becoming greatest at $24 \mathrm{~h}$ or $120 \mathrm{~h}$, while the synthesis of PP9 was initiated between 24 and $120 \mathrm{~h}$. The starvation-induced outer membrane protein OMP1 was only detected at 5 and $10 \mathrm{~h}$ of starvation and OMP2 and OMP 3 were only seen at 3,5 and $10 \mathrm{~h}$ of starvation.

\section{Protein degradation}

Complete energy and nutrient starvation caused a marked increase in protein degradation as compared to growth. During the initial phase of starvation, S14 exhibited a proteolysis rate of $5 \%$ per hour, as against $0.3 \%$ for growth on complete medium or $1 \%$ for growth on amino-aciddepleted medium (Fig. 5). The labelling procedure used in this study leads to the incorporation of the label into relatively stable proteins (Miller, 1987), and it is the degradation of these that is reflected in the rates of proteolysis. 


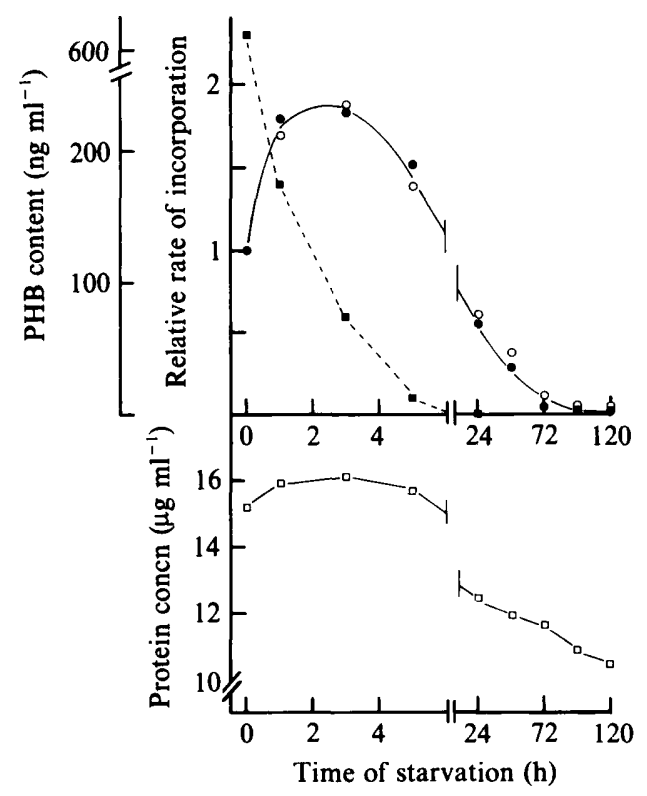

Fig. 6. Changes in protein concentration $(\square)$, relative rate of leucine $(O)$ and methionine $(O)$ incorporation per unit dry weight, and PHB concentration $(\square)$ during $120 \mathrm{~h}$ starvation. The relative rates of amino acid incorporation were related to the incorporation rate obtained at the onset of starvation, which was assigned a value of 1.0 . The PHB and amino acid incorporation data were adapted from Odham et al. (1986) and Nyström et al. (1986), respectively. Reproduced with permission from Applied and Environmental Microbiology and FEMS Microbiology Ecology.

Viability of S14 during heat- and ethanol-shock

The heat and ethanol treatments immediately inhibited growth of $\mathrm{S} 14$ cells. However, no cell lysis could be detected and the number of respiring cells remained $100 \%$ during the treatment as determined by the method of Zimmerman et al. (1978). S14 also remained $100 \%$ viable as determined by both c.f.u. and the number of respiring cells throughout the starvation period studied $(120 \mathrm{~h})$.

\section{DISCUSSION}

The importance of protein degradation for the survival of $E$. coli $\mathrm{K} 12$ and $S$. typhimurium during carbon starvation has been demonstrated by the use of peptidase-deficient mutants (Reeve et al., 1984a). These mutants displayed an impaired starvation survival response in comparison to the wild-type. The function of protein degradation in starving cells may be to provide amino acids for the synthesis of new survival-related proteins, as well as to inactivate proteins deleterious to starving cells. However, the increased rate of proteolysis demonstrated in this study may be due to the fact that certain enzymes become more susceptible to degradation when their substrates are present in decreasing amounts during starvation (Miller, 1987). The experimental protocol followed allows for only a limited characterization of protein degradation. Only changes in relatively stable proteins of growing cells can be detected. Since fewer than 50 proteins comprise more than $50 \%$ of the bulk protein in E. coli (Miller, 1987), calculations of protein degradation can be misleading. Large quantitative changes can mask smaller, and perhaps more important, qualitative changes.

Starvation induces temporal and transient changes in the protein composition of the marine Vibrio S14. The greatest number of changes was detected at 3 and $5 \mathrm{~h}$ of starvation, which may coincide with the utilization of the accumulated storage polymer poly- $\beta$-hydroxybutyrate (PHB) 
(Mårdén et al., 1985). An attempt to correlate the rate of protein synthesis (Nyström et al., 1986), total amount of protein and utilization of PHB (Mårdén et al., 1985) is presented in Fig. 6. Increased incorporation rates of leucine and methionine (Nyström et al., 1986), and an increase in respiration rate (Mårdén et al., 1985) during the first 3 to $4 \mathrm{~h}$ as compared to the onset of starvation have been demonstrated for S14.

The most common synthesis pattern of starvation proteins in S14 is exemplified by PP5, with a maximum in rate of synthesis during the first few hours of starvation (Fig. 4). However, some proteins increased throughout the starvation period, although the time at which they were induced ranged from 0 to more than $24 \mathrm{~h}$ after the onset of starvation. It is possible that several regulons are involved in a sequential starvation response of S14. These may be induced by exogenous as well as a series of time-dependent endogenous energy and nutrient shifts.

Some of the initial-phase starvation proteins may also be involved in the response of S14 to heat- and ethanol-shock. The overlapping proteins appeared to belong to those induced during the first hours of starvation, and displayed the kinetics of the PP5 protein. The extent of overlap in response to various stress stimuli varies between strains and conditions (Groat \& Matin, 1986; Spector et al., 1986; Morgan et al., 1986). Recognized features of several global regulatory networks, in particular the heat-shock response, involve the role of stress-response-specific proteases (Miller, 1987; Gottesman, 1987; Neidhardt, 1987). A role for the production of starvation-specific proteases in the survival of Vibrio S14 during exogenous energy and nutrient deprivation may be suggested. However, the importance of proteolysis during the long-term as well as the initial phase of starvation needs further investigation.

Additional functions of the starvation-specific proteins observed in this study may be suggested. Some of the proteins induced in S14 during nutrient and energy deprivation may be involved in substrate capture and transport. Mårdén et al. (1987) showed that two separate binding-protein-dependent uptake systems for amino acids were differently modulated during starvation. The $V_{\max }$ of the high-affinity uptake system increased during starvation, while the opposite occurred for the low-affinity system. Another aspect of substrate capture during starvation is indicated by the production of extracellular proteases by S14 cells (unpublished data). Proteases capable of degrading a wide range of substrates were exuded even after cells were starved for $120 \mathrm{~h}$.

The outer membrane protein profiles of S14 resembled those of $E$. coli (Owen et al., 1987) and Klebsiella aerogenes (K. pneumoniae) (Sterkenburg et al., 1984) with OmpF,C,A-like proteins between 34 and $38 \mathrm{kDa}$. The influence of nutrient limitation on the outer membrane proteins of $K$. aerogenes has been studied by Sterkenburg et al. (1984). Ammonium limitation induced a $46 \mathrm{kDa}$ protein and glucose limitation a $48 \mathrm{kDa}$ protein in $K$. aerogenes; these proteins are comparable in size to OMP10 and OMP11 induced in starved S14 cells (Fig. 1). The outer membrane starvation-specific proteins may be involved in altering the capacity for $\mathrm{S} 14$ cells to adhere to surfaces. The increased adhesion to inanimate surfaces and increased degree of hydrophobicity of some marine bacteria during starvation has been reported (Kjelleberg \& Hermansson, 1984; Hermansson et al., 1987). The transient and/or permanent effect on adhesion and cell surface hydrophobicity by the starvation-induced outer membrane protein modulation is presently being investigated.

In conclusion, pulse-labelling demonstrated that all but one of the starvation-induced antigens detected by Albertson et al. (1987) were synthesized de novo. The antigen that failed to incorporate radioactive leucine may be non-proteinaceous since it was heavily stained by silver but not by Coomassie blue. Most of the starvation-induced proteins were found at $3 \mathrm{~h}$ of starvation; however, since new starvation proteins were also found at 5, 10, 24 and $120 \mathrm{~h}$, a sequential induction of genes may be hypothesized. Finally, the overlap among proteins induced by different stress conditions is extensive (Fig. 3). However, each stress also induces a unique group of proteins.

This study was supported by a grant from the Swedish Natural Science Research Council. 


\section{REFERENCES}

Achtman, M., Mercer, A., Kusecek, B., Pohl, A., Heuzenroeder, M., Aaronson, W., Sutton, A. \& SILVER, R. P. (1983). Six widespread bacterial clones among Escherichia coli $\mathrm{K} 1$ isolates. Infection and Immunity 39, 315-335.

Albertson, N. H., Jones, G. W. \& KJelleberG, S. (1987). The detection of starvation-specific antigens in two marine bacteria. Journal of General Microbiology 133, 2225-2231.

AMY, P.S. \& MoRITA, R. Y. (1983). Protein patterns of growing and starved cells of a marine Vibrio sp. Applied and Environmental Microbiology 45, 17481752.

GotTESman, S. (1984). Bacterial regulation: global regulatory networks. Annual Review of Genetics 18 , 415-441.

GroAT, R. G. \& MATIN, A. (1986). Synthesis of unique proteins at the onset of carbon starvation in Escherichia coli. Journal of Industrial Microbiology 1, 69-73.

Hermansson, M., Jones, G. W. \& KJelleberg, S. (1987). Frequency of antibiotic and heavy metal resistance and plasmids in bacteria of the marine air-water interface. Applied and Environmental Microbiology 53, 2338-2342.

Jouper-JAAN, $\AA$., DAHLlÖF, B. \& KJElleberG, S. (1986). Changes in the protein composition of three bacterial isolates from marine waters during short term energy and nutrient deprivation. Applied and Environmental Microbiology 52, 1419-1421.

KJELleberG, S. \& HeRmansson, M. (1984). Starvationinduced effects on bacterial surface characteristics. Applied and Environmental Microbiology 48, 497-503.

MARdÉn, P., Tunlid, A., MalmCrona-Friberg, K., Odham, G. \& KJelleberg, S. (1985). Physiological and morphological changes during short term starvation of marine bacterial isolates. Archives of Microbiology 142, 326-332.

MÅRdÉN, P., NYSTRÖM, T. \& KJElleberG, S. (1987). Uptake of leucine by a marine Gram-negative heterotrophic bacterium during exposure to starvation conditions. FEMS Microbiology Ecology 45, 233-241.

Miller, C. G. (1987). Protein degradation and proteolytic modification. In Escherichia coli and Salmonella typhimurium: Cellular and Molecular Biology, vol. I, pp. 680-691. Edited by F. C. Neidhardt. Washington DC: American Society for Microbiology.

Morgan, R. W., Christman, M. F., Jacobson, F. S., STORz, G. \& AMES, B. N. (1986). Hydrogen peroxide-inducible proteins in Salmonella typhimurium overlap with heat shock and other stress proteins. Proceedings of the National Academy of Sciences of the United States of America 83, 80598063.

MORITA, R. Y. (1985). Starvation and miniaturisation of heterotrophs, with special emphasis on maintenance of the starved viable state. In Bacteria in Their Natural Environments, pp. 111-130. Edited by
M. M. Fletcher \& G. D. Floodgate. London: Academic Press.

NeIDHARDT, F. C. (1987). Multigene systems and regulons. In Escherichia coli and Salmonella typhimurium: Cellular and Molecular Biology, vol. II, pp. 1313-1317. Edited by F. C. Neidhardt. Washington, DC: American Society for Microbiology.

NySTRÖM, T. \& KJELLEBERG, S. (1987). The effect of cadmium on starved heterotrophic bacteria isolated from marine waters. FEMS Microbiology Ecology 45, 143-151.

NySTRÖM, T., MÅrdÉn, P. \& KJElleberG, S. (1986). Relative changes in incorporation rates of leucine and methionine during starvation survival of two bacteria isolated from marine waters. FEMS Microbiology Ecology 38, 285-292.

ODHAM, G., TUNLID, A., WesterdahL, G. \& MÅRDÉN, P. (1986). Combined determination of poly- $\beta$ hydroxyalkanoic and cellular fatty acids in starved marine bacteria and sewage sludge by gas chromatography with flame ionization or mass spectrometry detection. Applied and Environmental Microbiology 52, 905-910.

OWEN, P., Caffrey, P. \& Josefsson, L.-G. (1987). Identification and partial characterization of a novel bipartite protein antigen associated with the outer membrane of Escherichia coli. Journal of Bacteriology 169, 3770-3777.

Reeve, C. A., Bockman, A. T. \& Matin, A. (1984a). Role of protein degradation in the survival of carbon-starved Escherichia coli and Salmonella typhimurium. Journal of Bacteriology 157, 758-763.

Reeve, C. A., Bockman, A. T. \& Matin, A. (1984b). Role of protein synthesis in the survival of carbonstarved Escherichia coli K12. Journal of Bacteriology 160, 1041-1046.

SPeCtor, M. P., Alibadi, Z., Gonzalez, T. \& Foster, J. W. (1986). Global control in Salmonella typhimurium: two-dimensional electrophoretic analysis of starvation-, anaerobiosis-, and heat shock-inducible proteins. Journal of Bacteriology 168, 420-424.

SterkenburG, A., Vlegels, E. \& Wouters, J. T. M. (1984). Influence of nutrient limitation and growth rate on the outer membrane proteins of Klebsiella aerogenes NCTC 418. Journal of General Microbiology 130, 2347-2355.

WHEELER, P. A. \& KiRCHMAN, D. L. (1986). Utilization of inorganic and organic nitrogen by bacteria in marine systems. Limnology and Oceanography 31, 948-1009.

Whitaker, J. R. \& Granum, P. E. (1980). An absolute method for protein determination based on difference in absorbance at 235 and $280 \mathrm{~nm}$. Analytical Biochemistry 109, 156-159.

ZIMMERMAN, R., ITURRIGA, R. \& BECKER-BIRCK, J. (1978). Simultaneous determination of the total number of aquatic bacteria and the number thereof involved in respiration. Applied and Environmental Microbiology 36, 926-935. 